\title{
UNCOVERING THE SERVICE PROFIT CHAIN IN THE CASINO INDUSTRY
}

\begin{abstract}
Purpose-This paper, from a marketing and management perspective, reviews the relevant literature germane to casino studies. The review discusses the major findings from previous studies, provides a critique and identifies research gaps for future studies. In particular, the research foci presented in this paper rest on the service profit chain (SPC) model. The review involves studies relating to the constructs of the chain model and comprises sections that are categorized based on the internal link between management and employees, the interaction between casino service employees and customers, and the profitability link.
\end{abstract}

Design/methodology/approach-The approach employed in the current study involves a systematic review of the relevant academic literature with a focus on SPC studies in the casino industry, along with critical evaluation and analysis to identify research gaps. Google Scholar, EBSCOHost, Science Direct, Emerald, and other academic databases were used to search relevant studies relating to casino and gambling research streams.

Findings-The review identifies several research gaps on the basis of the SPC link. Specifically, internal service quality needs more attention from both the practice and research points of view. Casino employee research should be extended to include personal traits and characteristics that may contribute to employee performance and loyalty. In the interaction between casino service providers and gamblers, more studies should be undertaken on the efficiency and effectiveness of marketing initiatives and promotions. Externally, the paper points out that more appropriate measurement of customer loyalty and casino profitability should be explored.

Implications-This review provides references to focusing on key competitive advantages and presents guidelines on improving business growth and profitability for casino managers. The paper also identifies research areas that future studies should attend to.

Originality-The paper is the first thorough literature review of gaming research on marketing and management with a focus on the service profit chain model. This review represents a new era of gaming research, extending the problem gambling research focus into a broader scope embracing other disciplines.

Keywords: literature review, casinos, service profit chain, marketing, management, tourism and hospitality 


\section{INTRODUCTION}

Casino gambling is a popular leisure activity for many individuals (Walker et al., 2005). The term “casino” traditionally refers to a public hall for music and dancing (Cotte and Latour, 2009). Casinos today refer to places that offer gambling entertainment, including slot and table game play. Gambling or gaming, defined as playing a game that may involve elements of chance and/or skill for a prize (UK Gambling Commission, 2005), can take various forms, such as casino gambling, horse races and sports betting, and lottery. Over the last two decades, casinos have evolved from the phenomenon of "build it and they will come" to a more competitive environment globally (see Thompson and Prentice, 2013).

Like any other service businesses, casino revenue growth and profitability are the results of coordinating efforts and interacting relationships among management, employees, and customers. The marketing triangle depicts the relationship between management and employees (internal marketing), between employees and customers (interactive marketing), as well as between the management and external customers (external marketing) (Grönroos, 1997). These relationships are exhibited in the service profit chain (SPC) model (see Figure 1), which was originally developed by Heskett et al. (1994). The model indicates that business profit and growth are stimulated primarily by customer loyalty; loyalty is a direct result of customer satisfaction; satisfaction is largely influenced by the value of services provided to customers; value is created by satisfied, loyal, and productive employees; employee satisfaction, loyalty, and productivity, in turn, result primarily from internal service quality management. This chain of relationships involves the interactions among the three parties, although the management-customer relationship appears to be indirect. 


\section{The Links in the Service-Profit Chain}

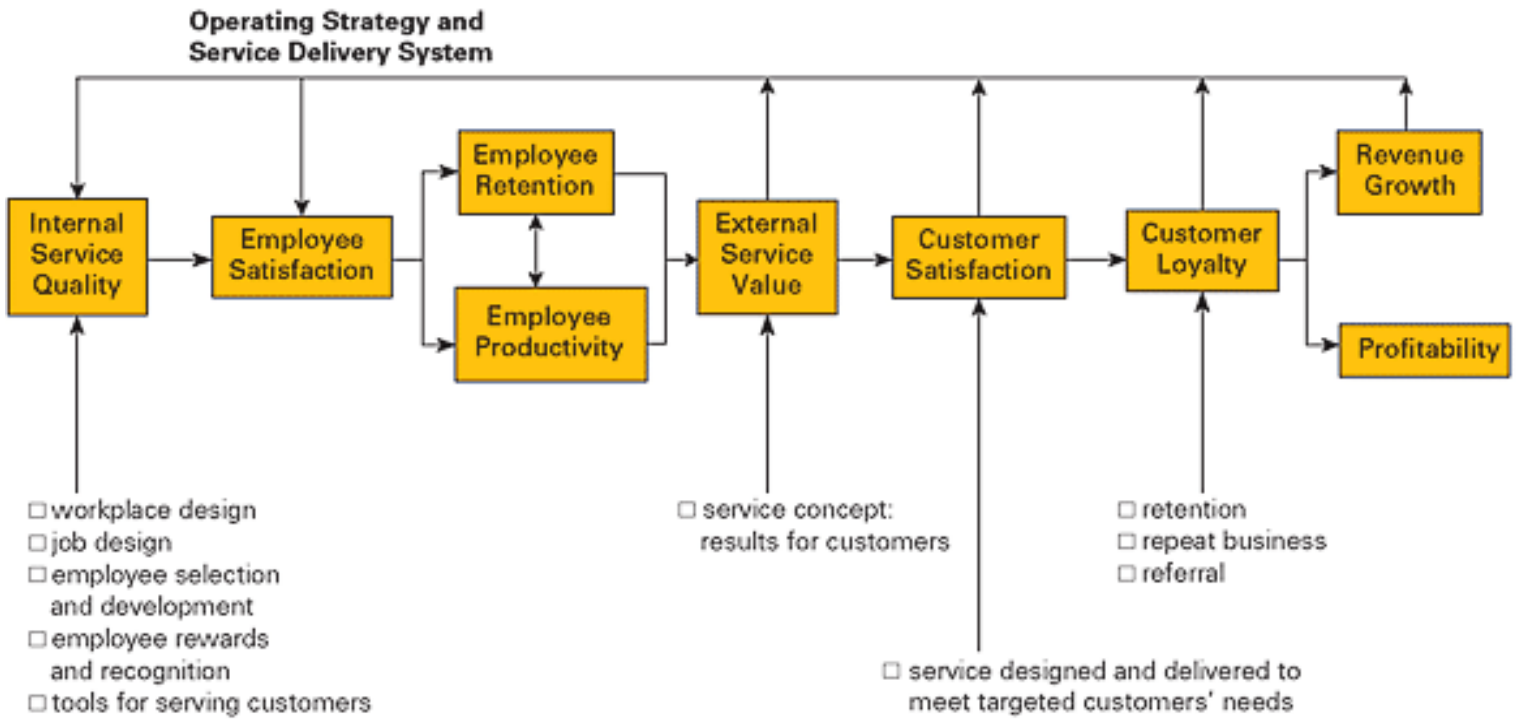

Figure 1. The links in the SPC from Heskett et al. (1994).

The casino business is inevitably dependent upon the coordination of elements along the profit chain to be viable (Heskett et al., 2013). Existing gaming research in the area of marketing and management has primarily focused on consumer behaviors and the relationships between casinos and customers. The current paper reviews the relevant literature on broad marketing and management research on casinos, discusses the major findings from previous studies, and identifies research gaps for future studies. The literature review follows the model and begins with the elements on the left side of the chain. The review involves studies relating to the constructs on the chain model and comprises sections that are categorized on the basis of internal links between management and employees, the interactions between employees and customers (between employee behaviors and customer perception of service value, and the link of customer perception of service quality, customer satisfaction, loyalty behaviors, and casino profitability (Figure 2). The review begins with a discussion of the topics in the general marketing and management literature, and then moves on to the relevant studies in the casino field. Each section discusses the major studies in the 
relevant area, followed by identifying research gaps and presenting recommendations. A summary of this review and future research directions conclude the paper.

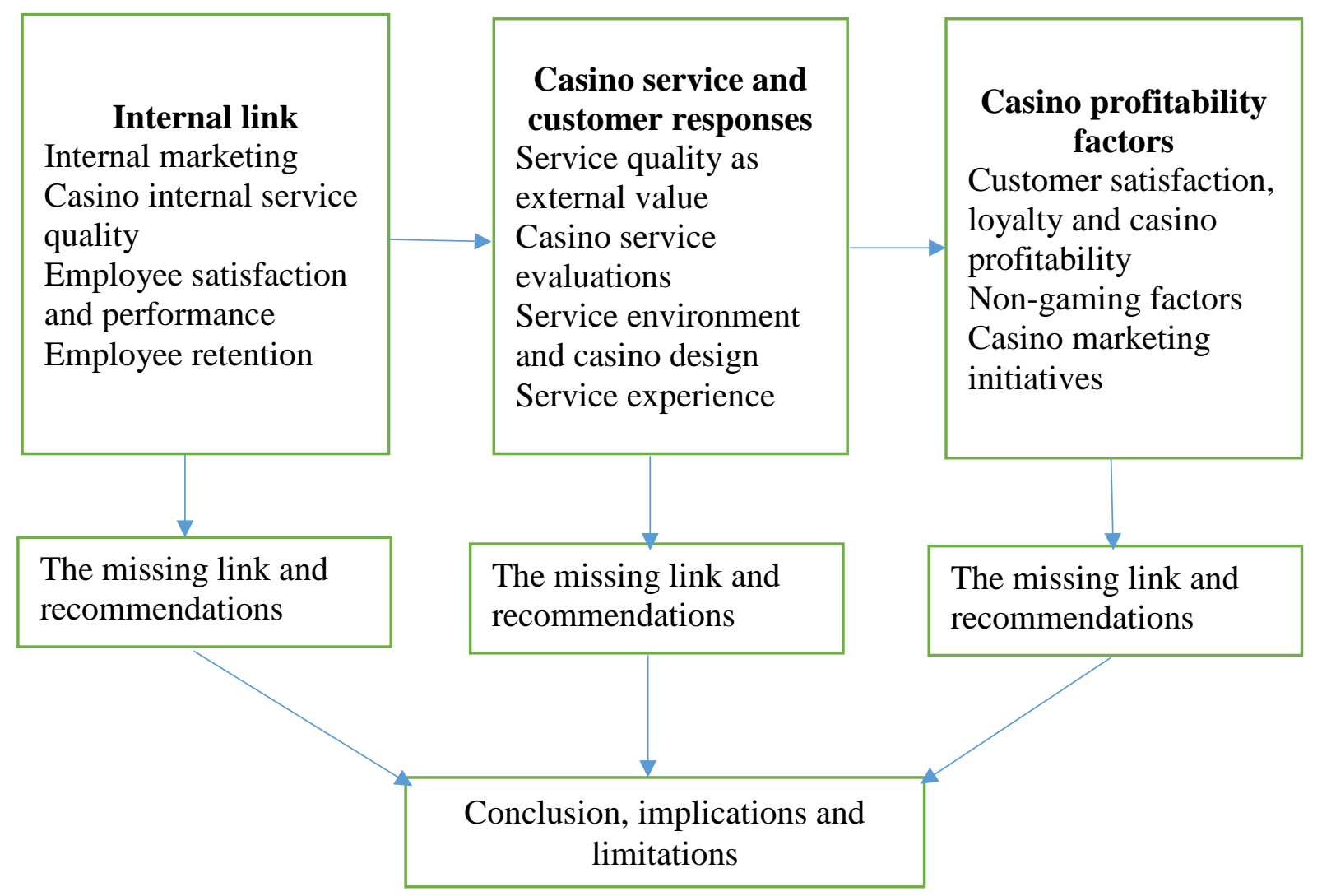

Figure 2. The framework of this paper. 


\section{METHOD}

\section{Data collection}

The current study employs Kitchenham’s (2004) systematic approach to reviewing the relevant literature with a focus on SPC and casino gambling, along with critical evaluation and analysis to identify research gaps in the casino industry. Google Scholar, EBSCOHost, SCOPUS, Science Direct, Emerald and other academic databases were used to search studies related to casino and gambling research streams. The review was conducted in an iterative manner during June 2015 - January 2016 to retrieve articles related to all relevant constructs that are included in the SPC model. Journal articles were retrieved from diverse fields of study: gambling/casino studies, tourism and hospitality, marketing and management.

\section{Review procedure}

This review involved a few steps. First, we searched publications on the concepts relating to the SPC model in marketing and management journals. Keywords used in this search included internal marketing, internal service quality, employee performance, customer value, service quality, customer satisfaction and loyalty, business revenue and profitability. We then conducted the search in tourism, hospitality and gaming journals with the same keywords. The second round of search was focused on gambling and casino related publications. Keywords included in the search are gaming, gambling, gambler, casino, casino marketing, casino management, casino employee performance, casino marketing, casino service and servicescape, gambler satisfaction; gambler loyalty, casino revenue, and profitability. The reference lists of each article were reviewed in detail to trace additional relevant articles.

Three senior researchers who have published extensively in the SPC area and in the gambling field conducted the review, evaluated the relevance of retrieved articles, and recorded the main findings of each study in a table. Selected articles were classified into three 
main areas: internal link between management and employees, interaction between service providers and customers, and external link between customer behaviors and business profitability. Reviewers assessed each article in the table for "inclusion” or "exclusion” based on the article's relevance to the topic. A consolidated list of search results featuring more than 300 journal articles was compiled by the three reviewers. Included articles described each construct in the chain model as well as those concepts relating to the constructs. For example, organizational commitment is related to employee retention. Any articles that examined the commitment in the casino industry were included in the review.

\section{REVIEW FINDINGS}

\section{The internal link: casino management and employees}

This section reviews all major studies relating to the relationship between internal service quality and employee attitudes as well as behaviors in the SPC model. The review begins with discussing internal marketing and service quality from the general marketing literature to casino studies. Employees’ attitudes and behaviors included in this section are primarily focused on employee satisfaction, retention, and turnover. Employee performance has relevance to customer attitudes and behaviors and is discussed in the next section. Analyses and critiques of the selected studies are presented in this review. Gaps are identified for future research. The areas of research that require greater attention are highlighted to conclude this section.

\section{Internal service quality}

The objective of the SPC is to provide an ideology on how human resources can be translated into revenue growth through the employees-customer link. Marketing researchers (Zeithaml et al., 1996) have long recognized the role of service employees in shaping customers' attitudes and behaviors. Employee satisfaction affects customer satisfaction (Schlesinger and Zornitsky, 1991), which results in customer loyalty (Anderson et al., 1994, 
Fornell, 1992). In practice, Sears' top management examined about 800 stores and discovered that a $5 \%$ increase in employee attitude scores resulted in a $1.3 \%$ increase in customer satisfaction and a $0.5 \%$ increase in revenue (cited from Lowenstein, 2008). This study supports the connection between employee satisfaction and overall profitability through the intervening effect of customer satisfaction. Employee attitudes and behaviors, according to the SPC framework, are attributed to internal service quality (Back et al., 2011, Hallowell et al., 1996).

The concept of internal service quality has been included in the relevant literature for over two decades, referring to the quality of service provided to employees of different departments within the same organization. Stauss (1995) defined internal service quality as employees’ perception and assessment of service quality provided by co-workers in one business unit to those in other units within the firm. Employees are referred to as internal customers who receive service from other members of the organization to carry out their jobs (Zeithami and Bitner, 1996).

Previous research shows that internal service quality has direct and indirect effects on job satisfaction and employee retention (Johnston, 2008, Kang et al., 2002). Training, motivation, and communication can enhance internal service quality, which subsequently affects employee satisfaction and productivity. Some studies extend the link and include its relationship with customer satisfaction (Hallowell et al., 1996). Most studies approach internal service quality by promoting organizational supporting activities on the basis of the equity theory introduced by Adams (1963). The theory describes how employees assess their job against the effort made as well as the reward received.

Despite its impact on driving employee attitudes and behaviors, internal service quality has received limited attention in the relevant literature and organizational context. Very few empirical studies have been undertaken to understand the impact of internal service 
quality on employees’ attitudes and behaviors in casino settings. Bai, Brewer, Sammons, and Swerdlow (2006) linked internal service quality with employee job satisfaction in a Las Vegas-based casino. They also explored the overall impact of job satisfaction and internal service quality on employee organizational commitment. Gu and Siu (2009) reported some aspects of casino internal service quality, including training opportunities, salaries and benefits, has a significant influence on employee satisfaction. Back, Lee, and Abbot (2011) found that all internal service dimensions, including training, communication, and perceived benefit, have a significant influence on casino employee job satisfaction, which subsequently enhances organizational commitment and employee retention.

Despite recognizing the importance of internal service quality, casinos have not adequately invested resources in improving employee job design, comprehensive training, incentive pay structures, and other internal practices (Kale and De, 2013, Kale and De, 2006). Employees react to unavailability of these practices with boredom, low motivation, poor job performance, and higher turnover rates (Chan et al., 2015). Given intensifying competition in this industry, it is imperative that casinos reevaluate their human resource management and incorporate strategies that not only reduce turnover rates but also return the focus and attention to factors enhancing employee job satisfaction and productivity.

\section{Employee satisfaction and performance}

As an outcome of practicing internal service quality, employee satisfaction, according to the SPC framework, has a direct influence on employee performance and retention. However, research has shown that the relationship between employee satisfaction and business performance is inconsistent (Lowenstein, 2008). Although Gu and Siu (2009) employed convenience sampling in Macau casinos and reported that job satisfaction is significantly related to job performance, the conclusion is rather simplistic. Job satisfaction is assessed from multiple dimensions including pay-related aspects and job attributes. 
Employees may be happy with certain aspects that meet individual needs. These aspects are not necessarily indicative of their job engagement, which predicts performance (Harter et al., 2002). In the case of casino employees, due to the intense working environment, they may receive a higher salary package than those in other service industries. However, these employees, especially those “casino-trained” croupiers, face job insecurity. Their employment opportunity is most likely limited to the casino industry. Job security, according to the SHRM report from Global Force (2015), has been consecutively ranked in the top five important factors in employee satisfaction and engagement across 10 years. Hence, when assessing casino employee satisfaction, it is imperative to understand and include the aspects that are crucial to specific employees to predict their job performance.

\section{Casino employee retention or turnover}

Employee retention is a direct outcome of job satisfaction and has an influence on customer loyalty and retention (e.g., Salanova et al., 2005). Employee turnover, particularly in the case of frontline employees, is prevalent in the tourism and hospitality industries. These employees perform the role of boundary spanners, dealing with customers and the organization. This boundary situation often positions them in various conflicts with customers, the management, or themselves (Prentice et al., 2013). Their job is characterized as emotional labor (Hochschild, 1983). Because of the nature of the fluctuating demand in most service industries, the organization has to stretch employee working hours or hire untrained part-time staff in the peak time and lay off employees in low seasons. Such capacity adjustment often leads to consequences of stress, burnout, and job dissatisfaction and insecurity in employees (see Prentice et al., 2013). Research has shown that employee satisfaction (Zopiatis et al., 2014) and organizational commitment (Mowday et al., 1982) are commonly recognized as important factors of employee loyalty and retention. Happy 
employees are committed to their employers, and employee commitment is manifest in their loyalty to the organization and employers.

Most research assesses employee commitment from the organizational perspectiveorganizational commitment (Back et al., 2011, Bai et al., 2006). Admittedly, organizational commitment explains employee retention. In the case of casinos, however, employee commitment and retention should be assessed and interpreted cautiously. The organization represents the casino where gambling activities take place. Research has shown that casino employees are at a high risk of gambling and problem gambling (Hing and Breen, 2008). Employee commitment and retention need to be distinguished from his or her preference for proximity to a gambling venue.

On the other hand, employee retention, like customer retention, is not necessarily indicative of loyalty. Their retention to the casino may be attributed to lack of job alternatives for those who have been working in the casino industry for a very long time, and have very limited skills that are able to accommodate other opportunities. In this case, employee retention is unlikely to be predictive of performance and productivity. To understand employee retention better, assessing organizational commitment is not adequate to capture employee commitment and loyalty. Because of the nature of gambling and its related social impact, individuals who have been victimized by gambling may prefer not to work in the casino industry. Indeed, Lai, Chan, and Lam’ (2013) study shows that casino dealers are unable to identify themselves with the casino or their occupation when they perceive their jobs to be morally questionable. Similar findings were reported by Wan, Wong, and Kong (2014) from the perspective of gaming students. Their findings revealed that these students expressed concern about the significance and social status of working in casinos. These factors could affect their occupational commitment as occupational disidentification and 
perceived social status often lead to a low level of organizational and industry commitment (Wan et al., 2014).

Casino operator's initiatives on corporate social responsibility (CSR), directed toward both the society and stakeholders, have a large impact on employee turnover intention (Lee and Park, 2009). Employees prefer to work for casino brands that portray an image of caring for the good of the society and various stakeholders (Liu et al., 2014a). Casinos that are perceived to have a higher level of CSR performance are more preferred employers. These casinos enjoy a higher level of brand quality, brand preference, and customer loyalty (Liu et al., 2014c, Liu et al., 2014b). In turn, CSR performance by casino operators is significantly associated with revenue, market share, and overall financial performance (Vong and Wong, 2013).

\section{The missing link and recommendations}

This section reviews all relevant studies from the marketing and management perspectives on the SPC's internal link involving internal service quality, employee satisfaction, performance, and retention. The review shows that prior research on internal marketing and service quality relating to the SPC model is primarily focused on job aspects such as pay, training, and job design. Very little attention is paid to factors that are not directly related to work but may have an impact on employee work attitudes and behaviors. These factors, such as childcare facilities, reliable means of transportation to work, flexible working hours, and access to health insurance in some countries, can contribute to employee satisfaction. Research relating to work-family conflicts, organizational support, and organizational climate may have a different effect on casino employees’ job-related behaviors, depending on the family life cycle, stage of career development, position, and other individual factors (e.g., personality) of these stakeholders. 
On the other hand, individual characteristics may also play a significant role in employee satisfaction and performance (Prentice and King, 2011). Working in casinos, especially a position that has direct contact or business transactions with gamblers (e.g., casino croupiers and hosts), requires a high level of stress tolerance and negotiation skills. Gamblers, like any other customers, are emotional. Their emotions could be more intense as a result of their gambling activities (Prentice and King, 2011). The encounter between casino employees and clients is highly emotionally charged. Employees must possess a certain level of emotional intelligence to manage the emotionally loaded encounters. Failure to manage the emotional encounter and soothe customer emotions may result in employee job dissatisfaction, poor performance, and high turnover. Consistent with this view, future research should add personal attributes (i.e., emotional intelligence) to the SPC model to gain a better understanding of employee performance, satisfaction, and retention.

\section{Casino service and customer responses}

This section focuses on the link between casino service provisions (i.e., employee service performance and casino service quality) and customer perception of value. The issues involving casino service quality measures and the relevant impact are elaborated. The discussion is focused on how customers respond to service stimuli and cues. The review also extends to discuss customer service experience. The research gap and recommendations are presented to conclude this section.

\section{Service Quality as External Value}

Employee service performance and productivity derived from internal service quality can be transferred to customer perception of service quality. Firms with efficient operating strategy and service delivery not only improve service productivity through satisfied and loyal employees but also further enhance customer value in the service delivery process (Heskett et al., 1994). Value is defined as the difference between cost and benefit received 
(Zeithaml, 1988). In the gaming context, value is mostly indicative of functional benefits, and assessed by money spent and gaming services received (Tsai et al.; Wong and Dioko, 2013). Nevertheless, benefits associated with gaming are only some of the many factors that attract gamblers (Lucas, 2003, Yi and Busser, 2008) as casino patrons look for more than table and slot games, winning money, and other functional benefits such as complimentary services.

To capture customer value and improve customer experience, casino operators have designed offerings that go beyond table games and have relentlessly sought ways to satisfy an array of gambler needs in order to build a long-term profitable relationship with their patrons (Barsky and Tzolov, 2010; Prentice and Wong, 2015; Wan, 2011). Casinos have evolved in seeking new ways to differentiate their brands and properties through better service quality in respect to the tangible and intangible attributes. The tangible aspect of casino services is referred to as technical quality, such as table games, amenities, facilities, and the atmosphere (McCain et al., 2005, Mayer and Johnson, 2003, Wong and Prentice, 2015); the intangible aspect of casino services is often referred to as functional quality germane to the employee service delivery process promptness, service reliability and accuracy, and employee empathy and professionalism.

While McCain et al.’s (2005) service quality measure is primarily based on Grönroos’s (1984) model, other researchers (Prentice et al., 2012; Shi et al., 2014) apply Parasuraman et al.'s (1991) seminal SERVQUAL model in the casino context with measures of service quality in five core dimensions: reliability, assurance, empathy, responsiveness, and tangibles. From a conceptual standpoint, the first four dimensions of SERVQUAL correspond to the service delivery performed by the employees with emphasis on service promptness, accuracy, consistency, and employee friendliness and caring. The last dimension corresponds to the physical setting of a casino, with an emphasis on the facilities and equipment. 
However, Wong and Fong (2012) argue that these two quality models fail to take into account the importance of the service encounter and are too generic without considering the context of casinos. To address these limitations, Wong and Fong developed the casino service quality (CASERV) model with emphasis on four core service areas in the casino service encounter: game service (e.g., slot and table games), service environment (e.g., ambience, facilities, and décor and layout), service delivery (employee service promptness, consistency, and personal attention), and food service (e.g., variety and quality of food and drinks). Several studies have adopted the CASERV model and validated the scale in various casinos, and assessed the antecedents and consequences of the four casino service aspects (Marković and Krnetić, 2014, Zeng and Prentice, 2014, Prentice, 2013a, Prentice and Woodside, 2013); Zeng and Prentice, 2014). The results suggest that the scale is robust and able to account for a significantly large portion of gambler outcomes, such as customer satisfaction and loyalty.

Other variations of instruments have been developed to assess different aspects of casino services. For example, Lo et al. (2013) view service quality in casinos germane to five factors: tangibles, fairness, responsiveness, professionalism, and variety of activities. Gu and Siu’s (2008) study focused on the employee service delivery and demonstrated the importance of casino dealer behaviors, such as communication skills, ability to avoid mistakes, willingness to help players, greetings and smiles, respect for players, and serving skills on customer satisfaction.

\section{Casino Service Evaluations}

Although a large body of the literature has reported the pivotal role of service quality in the casino service encounter, service evaluations are found to be contingent on gambler characteristics. For example, McCain et al. (2005) reveal that hardcore loyal players rate both the technical and functional service qualities significantly higher than potential switchers. Wong et al. (2012) suggest that male and hardcore gamblers generally have a more favorable 
evaluation of casino services (i.e., game service, service environment, and employee service delivery) due to their intense interaction and involvement in the casino; hence, these patrons tend to have a higher level of satisfaction.

Prentice and colleagues (Prentice, 2013b, Prentice, 2014) have conducted extensive research on investigating the role of player types on service quality evaluations. For example, the authors compare the differences between casino loyalty members and non-members and show that non-members tend to have a higher evaluation of the service environment, food service, and employee service delivery than members do (Shi et al., 2014, Zeng and Prentice, 2014). Prentice et al. (2012) examined the discrepancies between four different levels of loyalty card players. Their findings reveal that while basic membership card (i.e., green card) holders have a negative sentiment about casinos' service quality, premium membership card holders have a positive attitude and perceptions. The study demonstrates a need to link different market segments with the corresponding tier services, as the VIP customers or high rollers are by far the most important cash cow to casino operators (Watson and Kale, 2003). An interesting finding in Prentice’s (2014) study reveals that high rollers dislike personal or individualized attention (empathy) from the casino, contrasting with other studies that show empathy from service employees plays a significant role in customer satisfaction and loyalty. Prentice and Woodside (2013) further reveal that problem gamblers tend to view casino services with a harsh gaze and evaluate these services lower than non-problem gamblers.

\section{Service Environment and Casino Design}

As part of the casino service proposition, the service environment is perhaps the most important element in casinos, as research commonly suggests that it is the most salient factor that affects player satisfaction and behavioral outcomes (Wong and Fong, 2010, Prentice and Woodside, 2013). One of the major reasons is that the physical environment is vividly visible to gamblers and hence, they tend to have a higher evaluation of this service aspect than other 
service components (Wong et al., 2012, Shi et al., 2014). Largely based on environmental psychology and stimulus-response theory, research on the service environment consistently suggests that the physical setting exercises stimuli to customers; a well-designed surrounding is attractive, which leads to certain behaviors such as favorable attitudes and response toward value propositions from the service provider (Bitner, 1992). Because services are intangible by nature, the tangible environment often serves as the most salient cue to differentiate a casino brand's position, a means to set customer expectations, and an avenue to communicate a brand's service experience (Wong and Wu, 2013, Zhang et al., 2009). This may explain why contemporary casinos, such as the Bellagio, Caesars Palace, Marina Bay Sands, and Studio City, are built like palaces and theme parks that offer endless wonders with integrated facilities and services (e.g., accommodation, retail outlets, event venues, entertainment spots, and gambling areas).

In turn, consumers imbue tangible service elements with meanings leading to desirable consumer emotional and behavioral responses. Early gaming research focused on the ambient conditions and atmospheric appeals, such as music, scent, background color, and surroundings in altering player behaviors. For example, Mayer and colleagues (Johnson et al., 2004; Mayer and Johnson, 2003) show that gamblers perceive casino atmospherics to comprise the theme, décor, lighting, noise level, color, ceiling height, temperature, floor layout, employee uniforms, and smell. Marmurek et al. (2007) showed that patrons exposed to pleasing music have a higher level of at-risk gaming intention and liking of a casino. Music increases at-risk gambling intention in a playground setting (e.g., a room designed with warm colors, spacious, and vegetation that evoke security and comfort), whereas it decreases at-risk gambling intention in a traditional gambling room rendering.

Noseworthy and Finlay (2009) examined the effect of music on slot machine playing time, and show that players often underestimate the elapse of their playing time with an 
ambient gambling background noise, while music promotes estimation confidence and hence, better accuracy of such an estimation. Hirsch (1995) demonstrates that certain odorants could improve players' senses and arousal and hence, they spend more on gambling. These results suggest that the environmental stimuli must be carefully crafted to be congruent with the intended consumer responses.

Other researchers assess the relationship between the service environment and gambler outcomes with an emphasis on a broader appeal to discerning patterns about the role of various environment factors. For example, Lucas (2003) investigated the effect of servicescape on slot play satisfaction and behavioral intention. The researcher measured servicescape in terms of ambient conditions, casino navigation, interior décor, cleanliness, and seating comfort. The results show that servicescape elements can positively influence individuals' repatronage intention and their desire to stay within the casinos. These five environment factors were further examined by Lam et al. (2011) to demonstrate different impacts on both cognitive and affective customer satisfaction. Lio and Rody’s (2009) study shows that seating comfort, cleanliness, and interior décor are significant predictors of overall servicescape, which further leads to positive gambler emotion and approach responses to the casino. Liu and Wan (2011) examined the factors that discourage slot play in Macau's casinos. Contrary to previous studies, the researchers found that servicescape has a minimal impact on gamblers' slot play. Instead, the nature of the games and the provision of good services appeared to play a bigger role in the adoption of slot games.

Wan’s (2013) more recent study moves beyond the servicescape model to embark on a comprehensive casino design that focuses on the factors of design preferences and aesthetics such as spacious and open, architectural style, exterior design, interior décor, theme, signage, and floor layout. Based on both consumer psychology and organizational resource perspectives, Wong and Prentice (2015) took another step forward and assessed the 
service environment and its impact at both individual and casino levels. Their findings not only show that the service environment provokes gambling impulse at both levels but also illustrates a need to take into account both cross-level direct and moderating effects emanating from the casino’s physical setting as an organizational-level value proposition.

\section{Service Experience}

With intensified competition and much-improved services among casinos around the globe, gamblers look beyond basic services and table games nowadays as they are looking for casinos that could exceed their expectations. Research shows that gambler expectations of a casino play a moderating role in the value chain leading from perceived performance to customer satisfaction through the mediating role of perceived value (Wong and Dioko, 2013). Because patrons look for more and better services, astute providers must fulfill the constellation of experiences that patrons seek. According to Pine and Gilmore (1998), today's economic transactions have progressed into experience-oriented encounters dominated by staged service experiences that differentiate providers primarily based on hedonic offerings, and are backed by customers' needs for sensations, emotions, and fantasies (Hirschman and Holbrook, 1982).

In respect to gambler experience, early work from Cotte (1997) suggests that gamblers seek an array of experiences in respect to learning and evaluating, rush, selfdefinition, risk taking, cognitive self-classification, emotional self-classification, competing, and communing. These sought experiences are cast within a continuum of intrapersonal versus interpersonal as well as rational and functional versus hedonic factors in a two-by-two matrix. However, as demonstrated above, player service experience also plays a critical role in their responses. Gilmore and Pine (1998) further argue that only memorable experience lasts, which suggests that casino service experience has a cascading effect on gamblers' longterm loyalty. This proposition has been confirmed in the literature in that patrons who enjoy 
their experience in casinos often expressed greater loyalty propensity and actual behaviors through brand preference, patronage, word of mouth, and willingness to spend more (Lucas, 2003, Wong, 2013, Zhang et al., 2009). Building a strong brand with memorable service experience has significant implications to casinos as properties with a favorable position in the mind of gamblers often enjoy a greater competitive advantage with loyal customers (Wong and $\mathrm{Wu}, 2013$ ). Based on Wong and Wu's experience perceptual map, which is used to gauge the experiential position of casinos, renowned properties such as the Venetian, Wynn, and MGM are leaders in discerning a higher level of service experience than rivals in the gaming industry in Macau; in turn, these operators have become global leaders in the industry.

In respect to the casino setting, researchers began to explore service experience more than a decade ago. The work from Lucas (2003), for example, indicates that customer experience in casinos could be derived from the service environment, gaming value, prompt service, and staff friendliness. Zhang et al. (2009) assess experiential value based on eight elements: aesthetics, entertainment, enjoyment, escape, efficiency, economic, excellence, and social interaction. Based on the conceptual work of Pine and Gilmore (1998), Wong and colleagues reconceptualized the customer equity model and proposed that service experience equity supersede value equity, which is defined as a constellation of lavished services including the service environment, employee service, service convenience, and hedonic service (Wong, 2013). From a broader definition, experience attributes may include value, novelty, brand experience, and perceived luck in addition to the four attributes of service experience equity mentioned above (Wong and $\mathrm{Wu}, 2013$ ). In turn, each of these attributes contributes to provide a total service experience that casino patrons seek. Using these experiential attributes, Wong and $\mathrm{Wu}$ (2013) demonstrated a procedure so that practitioners could vividly identify the service experience position of casinos through a perceptual map. 
Using this experiential positioning method, casino operators could gain insights into their current position relative to industry rivals and a means to differentiate their brands.

\section{The missing link and recommendation}

This section reviews the link of casino service offerings and customer evaluation of these offerings. The discussion is extended to include customer service experience. Although a plethora of research has been dedicated to discussing casino service quality and the relevant consequences, the review shows that use of service quality measures in casino studies is not united and that customers' responses toward service quality dimensions vary across the research settings. The aforementioned literature provides the necessary foundation on gamblers' experience, but few studies have investigated their experience in the casino/gambling context. Rosenbaum and Wong (2015) suggest that neither winning nor losing affects leisure gamblers’ restorative experience. However, Lam’s (2007) study on Chinese hardcore gamblers shows that these patrons express frustration, anger, and agony in the case of losing. They further manifest these negative emotions by blaming the serving staff for causing them bad luck. Such inconsistency warrants more research in this area.

On the other hand, although prior research has investigated the impact of casino services, marketing proposition, and gambler responses on casino profitability, it has largely overlooked the roles of organizational- and destination-level factors on service design, marketing initiatives, and gambler behaviors. For example, it is rather unclear how public policy of a destination may interact with an organizational policy to influence casino strategies and offerings, which may ultimately affect gamblers' decisions and behaviors as well as casino profitability. A change in economic conditions and destination attractiveness, for example, may also play a salient role in organizational customer relationship policy (e.g., cutting complimentary or discounted food, rooms, and transportation for patrons) and 
customer service experience. These various factors may impact casinos’ brand equity and ultimately affect building a long-term customer relationship that drives casino revenue.

\section{Casino profitability factors}

This section reviews research on customer satisfaction, loyalty, and profitability in casinos, the link on the right side of the SPC model. Although the relationships among these constructs have been extensively discussed in the general marketing literature, this review provides a fresh look at these relationships in the casino context. Subsequently, the discussion elaborates on the research gap in this area.

\section{Customer satisfaction, loyalty, and casino profitability}

As mentioned above, casino operators have reaped value by delivering an exceptional service experience throughout the service encounter. Casinos have become an oasis for gamblers to fulfill an array of needs. In turn, superior casino services result in favorable responses with a higher level of arousal and dominant emotion (Lio and Rody, 2009), customer satisfaction and casino loyalty expressed in the form of revisit intention and positive word of mouth (Lam et al., 2011; Prentice, 2013a; Prentice, 2013b; Shi et al., 2014; Wong and Fong, 2010; Wong and Fong, 2012; Zeng and Prentice, 2014), lower propensity to complain (Wong and Dioko, 2013), and exercise more desirable gambling behaviors such as visiting the casino more often as well as spending more time and money on gambling than one intended (Wong and Prentice, 2015). While most studies define satisfaction primarily germane to the cognitive and affective route of customer response, Gao and Lai (2015) argue that customer satisfaction should be assessed in respect to the major casino service encounters and offerings in respect to shopping outlets, restaurants and food and beverage, casino floors, and accommodation. These transaction-specific satisfactions are found to be correlated with overall satisfaction and customers' propensity to revisit and recommend the casino. 
Gamblers' loyalty behaviors are also contingent on their personal characteristics. For example, Prentice and Woodside (2013) reveal that problem gamblers have a lower propensity to switch to other casinos and a higher propensity to spread positive word of mouth. Prentice (2014) segments gamblers into different groups on the basis of their betting volume, and reveal that the cause of propensity to switch and customer retention varies across the segments.

Customer loyalty has great financial implications for casino operators. For example, Tsai et al. (2015) identify that better financially performed casinos in Macau such as SJM, the Venetian, and Wynn are able to retain a higher level of brand image, brand awareness, and brand loyalty than less financially sound casinos. Baloglu and colleagues identified four types of gambler loyalty: true loyalty, latent loyalty, spurious loyalty, and low loyalty (Baloglu, 2002, Tanford and Baloglu, 2013). Truly loyal gamblers have a strong emotional commitment and trust in a casino; they also spend more time and visit the casino fairly often. Latent-loyal gamblers express a high level of emotional commitment and trust in a casino, but spend less and visit the casino less often than spurious-loyal gamblers who, however, express a lower level of trust and commitment to a casino. These three types of gamblers have a more favorable attitude toward reward programs, have a longer tenure of casino membership, and spend more time in the casino than low-loyalty gamblers do (Tanford and Baloglu, 2013).

Loyal big spenders are particularly desirable as they not only focus more of their trip spending on gambling, they also have a higher level of trip expenditure (i.e., above USD $\$ 120$ per trip) and annual expenditure (i.e., more than USD \$2,100) in a casino (Palmer and Mahoney, 2005). Watson and Kale (2003) apply the customer lifetime value concept to casino gamblers and show that increasing customer retention and upgrading players in the middle-tier to high-volume betting tier significantly increase the lifetime value of these 
patrons and hence, improve a casino’s long-term profit. Such a strategy could further reduce a casino’s high-risk junket segment.

\section{Non-gaming factors}

Besides game characteristics and service environment, researchers examined the impact of non-gambling and other gambling components within a casino property on slot performances. These studies, conducted mainly in the US, include the relationship between slot performance and showroom entertainment (Suh, 2011), restaurants' volume (Kalargyrou

et al., 2012, Lucas and Santos, 2003, Tanford and Lucas, 2011, Suh et al., 2012), and bingo (Lucas et al., 2006) as well as poker rooms’ performances (Lucas, 2013). These studies connect complimentary activities within the casino property to slot play behaviors. According to Roehl (1996), gamblers who use some amenities in a casino property, such as restaurants and coffee shops, are more likely to spend more on gambling than those who do not use these amenities. As such, research on the effect on non-gambling components within a casino property is relevant to casino revenue and profitability.

\section{Casino Marketing Initiatives}

Given that gamblers' spending is often associated with their length of stay, attitudes toward reward programs, and perceptions of casino services, operators have continually improved their marketing offerings and promotional mix to engage and attract patrons better. Contemporary casinos have blossomed into sprawling complexes that provide an integrated assortment of amenities and non-gaming products such as shopping, dining options, shows and entertainment, spas, and accommodation. These offerings keep gamblers on site and, hence, induce them to spend more on gambling (Roehl, 1996). Indeed, besides friendly employees and a comfortable atmosphere, contemporary casinos have striven tirelessly to offer additional services such as free shuttle services; complimentary food, drinks, and rooms; entertainment displays; promotional offerings; comfortable gambling amenities, and 
more (Wan, 2011, Wong and Wu, 2013). Food is a particularly attractive service product for casino patrons as it fulfills the most basic physiological need, and becomes one of the key service areas in Macau's casinos (Wong and Fong, 2012). While casino floors may serve simple snacks, sandwiches, and drinks, gourmet restaurants are often situated at the perimeters of the casino floors. Empirical evidence shows an indirect impact of casinooperated restaurants on gaming volume such as coin-in for slot games. Dining volume is particularly strong for low-volume slot play in the US (Tanford and Lucas, 2010, Lucas and Santos, 2003). Recent evidence also reveals that food and beverage service attracts specific segments of casino players (Prentice, 2014). This may explain why most of the Michelinstarred restaurants are located inside casinos in gaming meccas such as Macau and Las Vegas (Wong, 2015).

Another well-investigated area is the casino membership (known as loyalty or reward) card and its role in gamblers. Empirical evidence suggests that there is a positive correlation between possession of a membership card and intensity of gambling that may even lead to problem gambling (Prentice and Woodside, 2013). In turn, players with a membership card are more inclined to revisit the casino than those without a card (Shi et al., 2014). Players with a membership card often enjoy discounts and complimentary services. Such incentives are especially effective for patrons with spurious loyalty due to their low level of affective commitment to a casino (Tanford and Baloglu, 2013). However, offering discounts to all customers may hurt a casino’s financial bottom line despite gaining a competitive advantage in retaining patrons (Salmon et al., 2004). Indeed, evidence from Watson and Kale (2003) suggests that revenue hardly increases for incidental gamblers and marketing efforts should focus primarily on high-end and mid-tier segments.

(Lucas, 2004, Lucas et al., 2006) also investigated the relationship between casino promotions and gambler patronage and cash drop on games in the USA. Direct mail is a 
popular marketing tool to attract an influx of gamblers with higher gambling spending through slot incentives, slot coupons, match play coupons, special events (e.g., concerts), and complimentary rooms, although empirical results are mixed. Other promotional methods include cash drawing, slot and table tournament, player party, and club benefits (Lucas and Bowen, 2002, Lucas et al., 2006, Yi and Busser, 2008). Casino revenue soars with elevated level of gambling volume, cash drops, and customer retention (Watson and Kale, 2003).

Nevertheless, there is still a lack of academic research on the effectiveness of slot or table game promotions (Lucas and Bowen, 2002). Although specific slot promotions were investigated previously, these studies were limited in scope. For example, Suh (2012) tested high-value and low-value slot free-play coupons and found that high-value free-play coupons do not necessarily increase players' slot game play volume more than low-value coupons do. Suh et al. (2012) found that complimentary meals to players seem to have an impact on their slot gaming expenditure. More recently, Hing and colleagues (2015) found that gambling promotion has a great influence on problem gamblers who report more encouragement and influence to gamble. The authors suggest that more research should be conducted to understand how gambling promotions impact gambling consumption and problem gambling. Future studies should attend to these gaps revealed in these studies.

\section{The missing link and recommendation}

This section reviews the link of customer satisfaction, loyalty and casino profitability. The relevant factors in casino revenue growth are identified from existing studies, including customer satisfaction and loyalty, non-gaming factors, and marketing initiatives. The review shows that, to date, research has primarily focused on the factors in casino customer loyalty and potential revenue growth. The loyalty-profitability link has not received sufficient attention. In particular, most literature approaches casino profitability from customer retention rate and its implied revenue increase. Customer loyalty and retention were assessed 
primarily by respondents' self-report data through survey and experiment. This use puts a great limit on research application. Such limitation is attributed to the difficulty in accessing the actual casino data. To gain insights into the factors in ultimate casino profitability, future studies should seek more appropriate and accessible measurements. This would require researchers to work closely with casino operators and gain access to crucial customer behavioral data such as those relating to their average betting sizes and play duration. In a similar vein, casino-based tourism not only drives the profitability of operators but also helps attract streams of tourists to gaming destinations (Wong and Rosenbaum, 2012, Wong and Li, 2015). Future research can investigate the missing link between a casino operator's profitability and destination economy and tourism revenue as well as factors that can serve as a remedy of debased tourist experience due to losses in gambling.

That being said, a number of studies have attempted to draw a link between casino profitability and its antecedents with secondary data and actual behavioral data from operators’ databases (e.g., Watson and Kale, 2003, Lucas, 2004, Lucas et al., 2006, Tanford and Lucas, 2011). These studies provide more valid measures of relationships among casino marketing efforts, gambler behaviors, and casino revenues. Other research discerns casino profitability through a combination of survey and secondary data that are drawn from the public domain or from gambling establishments (Palmer and Mahoney, 2005, Tanford and Baloglu, 2013, Vong and Wong, 2013). The advantage of this approach lies in its ability to use both primary and secondary data to build more complex analysis in understanding the gambler-profitability link. However, marketing initiatives, gambler behaviors, and profitability rest at different levels of the echelon; conventional approaches such as chisquare, analysis of variance, $t$-test, correlation, regression, and structural equation modeling can only accommodate a single level of unit of analysis on the basis of aggregation and disaggregation of data, which result in biased estimates. Drawing a link between profitability 
and its antecedents often requires more sophisticated methods, such as a multilevel analysis that accommodates data traversing levels (Wong, 2016).

Another major limitation of the use of actual casino and survey data in many studies is the lack of generalizability beyond the participating establishments. Without controlling potential confounding factors residing at the casino level, results can be spurious. In fact, some of the inconsistent findings in casino studies can be attributed to the differences in the research context. For example, the relationship between casino services and gambler behaviors can differ substantially across various casino settings (see Prentice and Wong, 2016). Casino profitability studies can also benefit by estimating the long-term impact of casino efforts and gambling behaviors on the change in casino revenue. These proposals offer new avenues for future research on casino gambling.

\section{CONCLUSION}

This paper has reviewed the literature relating to casino marketing and management on the basis of the SPC model, involving discussion of the relevant constructs in the model. The review thoroughly discussed the findings of major studies in the respective areas and provided critiques. Each section concluded with the identification of the relevant research gap and suggestion for future studies. In a nutshell, three main research gaps were identified in this article. The first gap is germane to the internal link of SPC with respect to the relationship between the management and employees. The foci of this research gap lie on the lack of study on incumbents’ personal traits and emotions, work-family conflicts, organization support, and more. The second gap is reflective of casino service quality measures and the issues relating to customer service experience. The third gap hints at the external link of SPC with respect to the relationship among casino offerings, gambling behaviors, and profitability. The focus on this gap lies on the lack of attention to possible contingencies and contextual effects of different casino-level factors on the effectiveness of 
casino offerings and marketing initiatives, gambler responses, casino profitability, and relationships among these aspects.

\section{IMPLICATIONS}

On the basis of findings of the review, this paper has implications for researchers and practitioners in the relevant fields. The review involves analysis of all major studies on casino marketing and management with a focus on research relating to the SPC model and provides a critique on these studies. The analysis reveals merits of prior studies and research gaps for future research directions, as presented above. The critique provides insights into existing gaming research and its applications to the industry. The gaps and missing links identified in this review presents a useful reference and guideline for researchers in their future research endeavors. For casino practitioners, this paper can be a reliable source of information for them to draw on in order to improve their current practice and helps facilitate identifying useful research findings.

\section{LIMITATIONS AND FUTURE RESEARCH}

Despite a concerted effort in this review, the paper presents some limitations. First, this review is focused on casino-related literature primarily from the gambling, tourism, hospitality, marketing, and management disciplines. Research from other disciplines may be unintentionally neglected due to its lack of coverage in the hospitality aspect of casino gambling. Second, this study takes the SPC model as a guiding tool in laying out the structure of the article. This model covers the essence of both internal and external aspects of casino operations. More could be explored. Third, recommendations made in this study could be subjective, reflecting the authors' knowledge in the relevant fields, albeit the authors have published extensively in these fields. As the casino industry evolves, more research will emerge to advance our current understanding of this sector. 


\section{References}

Adams, J. S. (1963), "Towards an understanding of inequity", Journal of Abnormal \& Social Psychology, Vol. 67 No. 5, pp. 422-436.

Anderson, E. W., Fornell, C. and Lehmann, D. R. (1994), "Customer satisfaction, market share, and profitability: Findings from Sweden", Journal of Marketing, Vol. 58 No. 3, pp. 53-66.

Back, K.-J., Lee, C.-K. and Abbott, J. (2011), "Internal relationship marketing: Korean casino employees' job satisfaction and organizational commitment", Cornell Hospitality Quarterly, Vol. 52 No. 2, pp. 111-124.

Bai, B., Brewer, K. P., Sammons, G. and Swerdlow, S. (2006), "Job satisfaction, organizational commitment, and internal service quality: A case study of Las Vegas hotel/casino industry", Journal of Human Resources in Hospitality \& Tourism, Vol. 5 No. 2, pp. 37-54.

Baloglu, S. (2002), "Dimensions of customer loyalty: Separating the friends from the well wishers", Cornell Hotel \& Restaurant Administration Quarterly, Vol. 43 No. 1, pp. 47-59.

Barsky, J. and Tzolov, T. (2010), "The effectiveness of casino loyalty programs - Their influence on satisfaction, emotional connections, loyalty and price sensitivity", Marketing and Law.

Bitner, M. J. (1992), "Servicescapes: The impact of physical surroundings on customers and employees", Journal of Marketing, Vol. 56 No. 2, pp. 57-71.

Chan, S. H., Wan, Y. K. P. and Kuok, O. M. (2015), "Relationships among burnout, job satisfaction, and turnover of casino employees in Macau", Journal of Hospitality Marketing \& Management, Vol. 24 No. 4, pp. 345-374.

Cotte, J. (1997), "Chances, trances, and lots of slots: Gambling motives and consumption experiences", Journal of Leisure Research, Vol. 29 No. 4, pp. 380-406.

Cotte, J. and Latour, K. A. (2009), "Blackjack in the kitchen: Understanding online versus casino gambling", Journal of Consumer Research, Vol. 35 No. 5, pp. 742-758.

Fornell, C. (1992), "A national customer satisfaction barometer: The Swedish experience", Journal of Marketing, Vol. 56 No. 1, pp. 6-21.

Gao, W. B. and Lai, I. K. W. (2015), "The effects of transaction-specific satisfactions and integrated satisfaction on customer loyalty", International Journal of Hospitality Management, Vol. 44, pp. 38-47.

Global Force. (2015), "2015 employee recognition report: Culture as a competitive differentiator", available at: http://go.globoforce.com/rs/862-JIQ698/images/Globoforce_SHRM_2015.pdf (accessed March 20 2016).

Gronroos, C. (1984), "A service quality model and its marketing implications", European Journal of Marketing, Vol. 18 No. 4, pp. 36-44. 
Grönroos, C. (1997), "Value-driven relational marketing: From products to resources and competencies", Journal of Marketing Management, Vol. 13 No. 5, pp. 407-419.

Gu, Z. and Siu, R. C. S. (2008), "Industry labor force quality: An investigation from the customer service perspective", UNLV Gaming Research \& Review Journal, Vol. 12 No. 1/2, pp. 1-13.

Gu, Z. and Siu, R. C. S. (2009), "Drivers of job satisfaction as related to work performance in Macao casino hotels", International Journal of Contemporary Hospitality Management, Vol. 21 No. 5, pp. 561-578.

Hallowell, R., Schlesinger, L. A. and Zornitsky, J. (1996), "Internal service quality, customer and job satisfaction: Linkages and implications for management", Human Resource Planning, Vol. 19 No. 2, pp. 20-31.

Harter, J. K., Schmidt, F. L. and Hayes, T. L. (2002), "Business-unit-level relationship between employee satisfaction, employee engagement, and business outcomes: A meta-analysis", Journal of Applied Psychology, Vol. 87 No. 2, pp. 268-279.

Heskett, J. L., Jones, T. O., Loveman, G. W., Sasser, W. E. and Schlesinger, L. A. (1994), "Putting the service-profit chain to work", Harvard Business Review, Vol. 72 No. 2, pp. 164-170.

Heskett, J. L., Sasser, W. E. and Wheeler, J. (2013), The Ownership Quotient: Putting the Service Profit Chain to Work for Unbeatable Competitive Advantage, Harvard Business Review Press, Cambridge, MA.

Hing, N. and Breen, H. (2008), "Risk and protective factors relating to gambling by employees of gaming venues", International Gambling Studies, Vol. 8 No. 1, pp. 123.

Hing, N., Lamont, M., Vitartas, P. and Fink, E. (2015), "Sports bettors' responses to sportsembedded gambling promotions: Implications for compulsive consumption", Journal of Business Research, Vol. 68 No. 10, pp. 2057-2066.

Hirsch, A. R. (1995), "Effects of ambient odors on slot-machine usage in a Las Vegas casino", Psychology \& Marketing, Vol. 12 No. 7, pp. 585-594.

Hirschman, E. C. and Holbrook, M. B. (1982), "Hedonic consumption: Emerging concepts, methods and propositions", Journal of Marketing, Vol. 46 No. 3, pp. 92-101.

Hochschild, A. R. (1983), The Managed Heart: Commercialization of Human Feeling, University of Califonia Press, Bereley, CA.

Johnson, L., Mayer, K. J. and Champaner, E. (2004), "Casino atmospherics from a customer's perspective: A re-examination", UNLV Gaming Research \& Review Journal, Vol. 8 No. 2, pp. 1-10.

Johnston, R. (2008), "Internal service - barriers, flows and assessment", International Journal of Service Industry Management, Vol. 19 No. 2, pp. 210-231. 
Kalargyrou, V., Singh, A. K. and Lucas, A. F. (2012), "Estimating the effect of racino restaurant sales on slot wagering volume", International Journal of Contemporary Hospitality Management, Vol. 24 No. 7, pp. 1088-1099.

Kale, S. H. and De, S. (2006), "Five internal marketing approaches to combat Macau's labor shortage", in Third International Conference on Gaming Industry and Public Welfare 2006.

Kale, S. H. and De, S. (2013), "A diagnosis of inherent problems in enhancing service quality through internal marketing and organizational identification in Macau and Singapore casinos", UNLV Gaming Research \& Review Journal, Vol. 17 No. 1, pp. 31-42.

Kang, G.-D., Jame, J. and Alexandris, K. (2002), "Measurement of internal service quality: Application of the SERVQUAL battery to internal service quality", Managing Service Quality, Vol. 12 No. 5, pp. 278-291.

Kitchenham, B. (2004), "Procedures for performing systematic reviews", Keele University, Vol. 33, pp. 1-26.

Lai, J., Chan, K. W. A. and Lam, L. W. (2013), "Defining who you are not: The roles of moral dirtiness and occupational and organizational disidentification in affecting casino employee turnover intention", Journal of Business Research, Vol. 66 No. 9, pp. 1659-1666.

Lam, D. (2007), "An observation study of Chinese baccarat players", UNLV Gaming Research \& Review Journal, Vol. 11 No. 2, pp. 63-73.

Lam, L. W., Chan, K. W., Fong, D. and Lo, F. (2011), "Does the look matter? The impact of casino servicescape on gaming customer satisfaction, intention to revisit, and desire to stay", International Journal of Hospitality Management, Vol. 30 No. 3, pp. 558-567.

Lio, H.-L. and Rody, R. (2009), "The emotional impact of casino servicescape", UNLV Gaming Research \& Review Journal, Vol. 13 No. 2, pp. 17-25.

Liu, M., Wong, I. A., Chu, R., Shi, G. J., Brock, J. L. and Tseng, T.-H. (2014), "Can a socially responsible casino better retain its management staff? From an internal customer perspective", Asia Pacific Journal of Marketing and Logistics, Vol. 26 No. 4, pp. 520-539.

Liu, M. T., Wong, I. A., Chu, R. and Tseng, T.-H. (2014), "Do perceived CSR initiatives enhance customer preference and loyalty in casinos?", International Journal of Contemporary Hospitality Management, Vol. 26 No. 7, pp. 1024-1045.

Liu, M. T., Wong, I. A., Shi, G., Chu, R. and Brock, J. L. (2014), "The impact of corporate social responsibility (CSR) performance and perceived brand quality on customerbased brand preference", Journal of Services Marketing, Vol. 28 No. 3, pp. 181-194.

Liu, X. R. and Wan, Y. K. P. (2011), "An examination of factors that discourage slot play in Macau casinos", International Journal of Hospitality Management, Vol. 30 No. 1, pp. 167-177. 
Lo, A., Tsai, H. and Cheung, C. (2013), "Service quality of casinos in Macau: From the mainland Chinese perspective", Journal of China Tourism Research, Vol. 9 No. 1, pp. 94-114.

Lowenstein, M. (2008), "Profitably linking employee behavior to customer loyalty: driving Customer Commitment Through Employee Attitudes and Actions", available at: http://www.customerthink.com/files2/link_employee_behavior_to_customer_loyalty. pdf (accessed July 7 2016).

Lucas, A. F. (2003), "The determinants and effects of slot servicescape satisfaction in a Las Vegas hotel casino", UNLV Gaming Research \& Review Journal, Vol. 7 No. 1, pp. 119.

Lucas, A. F. (2004), "Estimating the impact of match-play promotional offers on the blackjack business volume of a Las Vegas hotel casino", Journal of Travel \& Tourism Marketing, Vol. 17 No. 4, pp. 23-33.

Lucas, A. F. (2013), "Estimating the impact of Las Vegas poker rooms on slot and table game business volumes: Does poker really carry its weight?", Cornell Hospitality Quarterly, Vol. 54 No. 4, pp. 347-357.

Lucas, A. F. and Bowen, J. T. (2002), "Measuring the effectiveness of casino promotions", International Journal of Hospitality Management, Vol. 21, pp. 189-202.

Lucas, A. F., Dunn, W. T. and Karitonova, A. (2006), "Estimating the indirect gaming contribution of bingo rooms", UNLV Gaming Research \& Review Journal, Vol. 10 No. 2, pp. 39-54.

Lucas, A. F. and Santos, J. (2003), "Measuring the effect of casino-operated restaurant volume on slot machine business volume: An exploratory study", Journal of Hospitality \& Tourism Research, Vol. 27 No. 1, pp. 101-117.

Marković, S. and Krnetić, M. (2014), "Casino service quality: Concept and measurement", Tourism \& Hospitality Management, pp. 364-379.

Marmurek, H. H. C., Finlay, K., Kanetkar, V. and Londerville, J. (2007), "The influence of music on estimates of at-risk gambling intentions: An analysis by casino design", International Gambling Studies, Vol. 7 No. 1, pp. 113-122.

Mayer, K. J. and Johnson, L. (2003), "A customer-based assessment of casino atmospherics", UNLV Gaming Research \& Review Journal, Vol. 7 No. 1, pp. 21-31.

McCain, S.-L., Jang, S. and Hu, C. (2005), "Service quality gap analysis toward customer loyalty: Practical guidelines for casino hotels", International Journal of Hospitality Management, Vol. 24 No. 3, pp. 465-472.

Mowday, R. T., Porter, L. W. and Steers, R. M. (1982), Employee-Organization Linkages: The Psychology of Commitment, Absenteeism, and Turnover, Academic Press, New York. 
Noseworthy, T. J. and Finlay, K. (2009), "A comparison of ambient casino sound and music: Effects on dissociation and on perceptions of elapsed time while playing slot machines", Journal of Gambling Studies, Vol. 25 No. 3, pp. 331-342.

Palmer, R. and Mahoney, E. (2005), "Winners and losers: Segmenting a casino loyalty programme", International Gambling Studies, Vol. 5 No. 2, pp. 271-287.

Parasuraman, A., Berry, L. L. and Zeithaml, V. A. (1991), "Refinement and reassessment of the SERVQUAL scale", Journal of Retailing, Vol. 67 No. 4, pp. 420-450.

Pine, B. J. and Gilmore, J. H. (1998), "Welcome to the experience economy", Harvard Business Review, Vol. 76 No. 4, pp. 97-105.

Prentice, C. (2013a), "Attitudinal and behavioral loyalty amongst casino players in Macau", Services Marketing Quarterly, Vol. 34 No. 4, pp. 309-321.

Prentice, C. (2013b), "Service quality perceptions and customer loyalty in casinos", International Journal of Contemporary Hospitality Management, Vol. 25 No. 1, pp. 49-64.

Prentice, C. (2014), "Who stays, who walks, and why in high-intensity service contexts", Journal of Business Research, Vol. 67 No. 4, pp. 608-614.

Prentice, C., Chen, P.-J. and King, B. (2013), "Employee performance outcomes and burnout following the presentation-of-self in customer-service contexts", International Journal of Hospitality Management, Vol. 35, pp. 225-236.

Prentice, C. and King, B. (2011), "Relationship marketing in the casino industry", Journal of Vacation Marketing, Vol. 17 No. 1, pp. 51-63.

Prentice, C., King, B. E. M. and Ohtsuka, K. (2012), "Casino service quality, tiered customer segments, and casino player retention", Services Marketing Quarterly, Vol. 33 No. 4, pp. 277-291.

Prentice, C. and Wong, I. A. (2015), "Casino marketing, problem gamblers or loyal customers?", Journal of Business Research, Vol. 68 No. 10, pp. 2084-2092.

Prentice, C. and Woodside, A. G. (2013), "Problem gamblers' harsh gaze on casino services", Psychology \& Marketing, Vol. 30 No. 12, pp. 1108-1123.

Roehl, W. S. (1996), "Competition, casino spending, and use of casino amenities", Journal of Travel Research, Vol. 34 No. 3, pp. 57-62.

Rosenbaum, M. S. and Wong, I. A. (2015), "When gambling is healthy: The restorative potential of casinos", Journal of Services Marketing, Vol. 29 No. 6/7, pp. 622-633.

Salanova, M., Agut, S. and Peiró, J. M. (2005), "Linking organizational resources and work engagement to employee performance and customer loyalty: The mediation of service climate", Journal of Applied Psychology, Vol. 90 No. 6, pp. 1217-1227. 
Salmon, J., Lucas, A. F., Kilby, J. and Dalbor, M. C. (2004), "Assessing discount policies and practices in the casino industry", UNLV Gaming Research \& Review Journal, Vol. 8 No. 2, pp. 11-25.

Schlesinger, L. A. and Zornitsky, J. (1991), "Job satisfaction, service capability, and customer satisfaction: An examination of linkages and management implications", Human Resource Planning, Vol. 14 No. 2, pp. 141-149.

Shi, Y., Prentice, C. and He, W. (2014), "Linking service quality, customer satisfaction and loyalty in casinos, does membership matter?", International Journal of Hospitality Management, Vol. 40, pp. 81-91.

Stauss, B. (1995), "Internal services: Classification and quality management", International Journal of Service Industry Management, Vol. 6 No. 2, pp. 62-78.

Suh, E. (2011), "Examining the indirect impact of showroom entertainment on hourly slot gaming volume: The case of a Las Vegas hotel-casino", International Journal of Hospitality Management, Vol. 30 No. 3, pp. 522-529.

Suh, E. (2012), "Estimating the impact of free-play coupon value on players' slot gaming volumes", Cornell Hospitality Quarterly, Vol. 53 No. 2, pp. 134-143.

Suh, E., Tanford, S. and Singh, A. (2012), "The indirect gaming contributions of cash and comped casino dining: Does providing complimentary meals pay off at the slots?", International Journal of Hospitality Management, Vol. 31 No. 4, pp. 1303-1310.

Tanford, S. and Baloglu, S. (2013), "Applying the loyalty matrix to evaluate casino loyalty programs", Cornell Hospitality Quarterly, Vol. 54 No. 4, pp. 333-346.

Tanford, S. and Lucas, A. F. (2010), "The indirect impact of casual dining on low-end gaming in destination and local casinos", International Journal of Hospitality Management, Vol. in press.

Tanford, S. and Lucas, A. F. (2011), "The indirect impact of casual dining on low-end gaming in destination and local casinos", International Journal of Hospitality Management, Vol. 30 No. 3, pp. 486-494.

Thompson, W. N. and Prentice, C. (2013), "Monopolies or open markets for casino industries", UNLV Gaing Law Journal, Vol. 4 No. 1, pp. 39-72.

Tsai, H., Lee, J. and Pan, S. (2015), "The relationships between casino quality, image, value, and loyalty", International Journal of Hospitality \& Tourism Administration, Vol. 16 No. 2, pp. 164-182.

UK Gambling Commission. (2005), "Gambling Act 2005", available at: http://www.legislation.gov.uk/ukpga/2005/19/pdfs/ukpga_20050019_en.pdf (accessed March 10 2016).

Vong, F. and Wong, I. A. (2013), "Corporate and social performance links in the gaming industry", Journal of Business Research, Vol. 66 No. 9, pp. 1674-1681. 
Walker, G., Hinch, T. and Weighill, A. (2005), "Inter- and intra-gender similarities and differences in motivations for casino gambling", Leisure Sciences, Vol. 27 No. 2, pp. 111-130.

Wan, Y. K. P. (2011), "Increasing Chinese tourist gamblers in Macao: Crucial player characteristics to identify and exploit", UNLV Gaming Research \& Review Journal, Vol. 15 No. 1, pp. 51-69.

Wan, Y. K. P. (2013), "Mainland Chinese gamblers' casino design preferences", Journal of Vacation Marketing, Vol. 19 No. 4, pp. 359-374.

Wan, Y. K. P., Wong, I. A. and Kong, W. H. (2014), "Student career prospect and industry commitment: The roles of industry attitude, perceived social status, and salary expectations", Tourism Management, Vol. 40, pp. 1-14.

Watson, L. and Kale, S. H. (2003), "Know when to hold them: Applying the customer lifetime value concept to casino table gaming", International Gambling Studies, Vol. 3 No. 1, pp. 89.

Wong, A. I. and Li, X. (2015), "Destination services and travel experience in the gaming mecca: The moderating role of gambling as a travel purpose among Chinese tourists", Journal of Travel \& Tourism Marketing, Vol. 32, pp. 80-99.

Wong, I. A. (2013), "Exploring customer equity and the role of service experience in the casino service encounter", International Journal of Hospitality Management, Vol. 32, pp. 91-101.

Wong, I. A. (2015), "Chinese outbound tourists' gaming behaviors: The emergence of casino tourism", in Li, X. R. (Ed.), Chinese Outbound Tourism 2.0. Apple Academic Press, Weartown, NJ, pp. 215-228.

Wong, I. A. (2016), "Linking firms, employees, and customers", Cornell Hospitality Quarterly, Vol. 57 No. 1, pp. 7-20.

Wong, I. A. and Dioko, L. A. N. (2013), "Understanding the mediated moderating role of customer expectations in the customer satisfaction model: The case of casinos", Tourism Management, Vol. 36 No. June, pp. 188-199.

Wong, I. A., Fong, H. I. V. and Liu, M. T. (2012), "Understanding perceived casino service difference among casino players", International Journal of Contemporary Hospitality Management, Vol. 24 No. 5, pp. 753-773.

Wong, I. A. and Fong, V. H. I. (2010), "Examining casino service quality in the Asian Las Vegas: An alternative approach", Journal of Hospitality Marketing \& Management, Vol. 19 No. 8, pp. 842-865.

Wong, I. A. and Fong, V. H. I. (2012), "Development and validation of the casino service quality scale: CASERV", International Journal of Hospitality Management, Vol. 31 No. 1, pp. 209-217.

Wong, I. A. and Prentice, C. (2015), "Multilevel environment induced impulsive gambling", Journal of Business Research, Vol. 68 No. 10, pp. 2102-2108. 
Wong, I. A. and Rosenbaum, M. S. (2012), "Beyond hardcore gambling: Understanding why mainland Chinese visit casinos in Macau", Journal of Hospitality \& Tourism Research, Vol. 36 No. 1, pp. 32-51.

Wong, I. A. and Wu, J. S. (2013), "Understanding casino experiential attributes: An application to market positioning", International Journal of Hospitality Management, Vol. 35, pp. 214-224.

Yi, S. and Busser, J. A. (2008), "The influential attributes that affect resident slot gamblers' repatronage intentions and willingness to recommend casinos to others", Journal of Hospitality Marketing \& Management, Vol. 16 No. 4, pp. 343-367.

Zeithami, V. A. and Bitner, M. J. (1996), Service Management, McGraw-Hill, New York.

Zeithaml, V. A. (1988), "Consumer perceptions of price, quality, and value: A means-end model and synthesis of evidence", Journal of Marketing, Vol. 52 No. 3, pp. 2-22.

Zeithaml, V. A., Berry, L. L. and Parasuraman, A. (1996), "The behavioral consequences of service quality", Journal of Marketing, Vol. 60 No. 2, pp. 31-46.

Zeng, Z. L. and Prentice, C. (2014), "A patron, a referral and why in Macau casinos —The case of mainland Chinese gamblers", International Journal of Hospitality Management, Vol. 36, pp. 167-175.

Zhang, J., Dewald, B. and Neirynck, B. C. (2009), "Experiential values for casino hotels in macao", Journal of Quality Assurance in Hospitality \& Tourism, Vol. 10 No. 2, pp. 75-92.

Zopiatis, A., Constanti, P. and Theocharous, A. L. (2014), "Job involvement, commitment, satisfaction and turnover: Evidence from hotel employees in Cyprus", Tourism Management, Vol. 41, pp. 129-140. 